\title{
Combination therapy of lamivudine and adefovir in Japanese patients with chronic hepatitis $B$
}

\author{
Satoshi Shakado $\cdot$ Hiroshi Watanabe $\cdot$ Takashi Tanaka $\cdot$ Daisuke Morihara \\ Shinya Nishizawa $\cdot$ Shinjiro Inomata $\cdot$ Syuichi Ueda $\cdot$ Teruo Matsumoto $\cdot$ \\ Akira Anan · Yasuaki Takeyama · Makoto Irie · Kaoru Iwata • \\ Tetsuro Sohda $\cdot$ Shotaro Sakisaka
}

Received: 29 June 2007 / Accepted: 27 April 2008/Published online: 30 May 2008

(C) The Author(s) 2008

\begin{abstract}
Purpose This study aimed to clarify the long-term efficacy of the lamivudine treatment in Japanese patients with chronic hepatitis B either with or without lamivudine resistance or with or without adefovir add-on treatment.

Methods We followed 110 patients who received lamivudine for more than 12 months, including 67 hepatitis B e antigen (HBeAg)-positive and $43 \mathrm{HBeAg}$-negative patients. Results The median follow-up after the onset of lamivudine was 48 (range $=12-86$ ) months. In all the patients with or without lamivudine resistance, the level of alanine aminotransferase (ALT) normalization decreased from $70.0 \%$ at 1 year to $36.4 \%$ at 5 years and the loss of serum
\end{abstract}

\author{
S. Shakado $(\bowtie) \cdot$ H. Watanabe $\cdot$ T. Tanaka $\cdot$ D. Morihara \\ S. Nishizawa $\cdot$ S. Inomata $\cdot$ S. Ueda $\cdot$ T. Matsumoto $\cdot$ A. Anan $\cdot$ \\ Y. Takeyama $\cdot$ M. Irie $\cdot$ K. Iwata $\cdot$ T. Sohda $\cdot$ S. Sakisaka \\ The Department of Gastroenterology and Hepatology, Fukuoka \\ University School of Medicine, 7-45-1 Nanakuma, Jonan-ku, \\ Fukuoka 814-0180, Japan \\ e-mail: shakado@cis.fukuoka-u.ac.jp \\ T. Tanaka \\ e-mail: tanaka329@minf.med.fukuoka-u.ac.jp \\ D. Morihara \\ e-mail: daipon0103@yahoo.co.jp \\ S. Nishizawa \\ e-mail: Shinya@minf.med.fukuoka-u.ac.jp \\ S. Inomata \\ e-mail: inomata@minf.med.fukuoka-u.ac.jp \\ S. Ueda \\ e-mail: Shushu@minf.med.fukuoka-u.ac.jp \\ T. Matsumoto \\ e-mail: tmatsu@minf.med.fukuoka-u.ac.jp
}

HBV DNA level decreased from $72.7 \%$ at 1 year to $31.8 \%$ at 5 years. Sixty patients $(54.6 \%)$ developed a lamivudineresistant mutation, and this occurrence was more frequently observed in those who were $\mathrm{HBeAg-positive}(P<0.01)$, those with a low level of ALT $(P<0.05)$, and those with a high level of serum HBV DNA $(P<0.01)$. Thirty-six of 60 patients received adefovir in addition to lamivudine to treat breakthrough hepatitis. A Cox proportional hazards model analysis revealed the level of baseline HBV DNA to be the best predictive factor for the virus recrudescence (risk ratio $=0.466,95 \%$ confidence interval $[\mathrm{CI}]: 0.246-0.842$, $P=0.011$ ) and the breakthrough hepatitis (risk ratio $=$ $0.444,95 \%$ CI: $0.218-0.879, P=0.019$ ). We carefully monitored the efficacy of this treatment both in patients

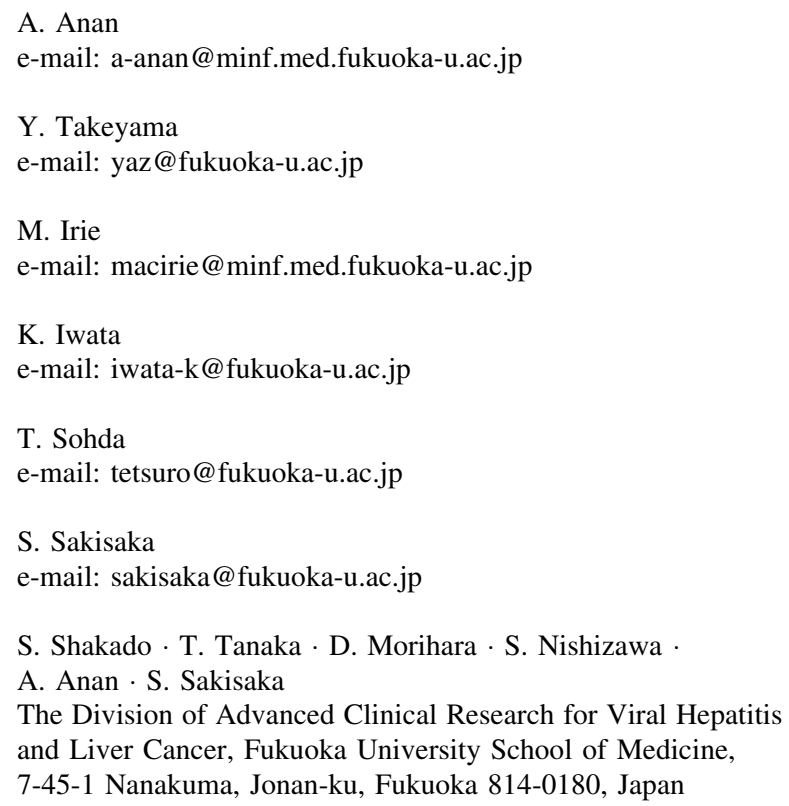


who received adefovir and in those who did not since the beginning of the lamivudine treatment. The normalization level of ALT was $61.4 \%$ at 5 years and the loss of serum HBV DNA was $61.4 \%$ at 5 years since lamivudine was started. A histologic improvement was observed in patients with ALT levels less than two times the upper limit of normal at the time of a second liver biopsy.

Conclusions Although the efficacy of lamivudine is limited because of breakthrough hepatitis, adefovir was used as a salvage treatment of patients with lamivudine-resistant chronic hepatitis B. In addition, lamivudine was used for the treatment of Japanese patients with chronic hepatitis B with or without lamivudine resistance, and was found to be useful regarding the long-term virologic and biochemical responses.

Keywords Chronic hepatitis B · Lamivudine · Adefovir

\section{Introduction}

The number of patients chronically infected with hepatitis $B$ virus (HBV) is reported to be more than 350 million worldwide $[1,2]$. These patients are at an increased risk to develop cirrhosis, hepatic decompensation, and hepatocellular carcinoma [3, 4]. The aims of treatment of chronic hepatitis B are to achieve a sustained suppression in HBV replication and remission in liver disease. The endpoints used to assess the treatment response include the normalization of the alanine aminotransferase (ALT) level, the loss of serum HBV DNA, the loss of hepatitis B e antigen $(\mathrm{HBeAg})$ with or without the detection of antibody to $\mathrm{HBeAg}(\mathrm{HBeAb})$, and an improvement in the liver histology.

Interferon, which has been shown to have an antiproliferative effect on the virus, has been used for the treatment of chronic hepatitis B; however, its efficacy has been limited to only a small percentage of preselected patients $[5,6]$. Lamivudine is the first nucleoside analog to be approved for the treatment of the patients with chronic hepatitis B. Although the short-term efficacy of lamivudine therapy has been well documented, the occurrence of lamivudine-resistant mutations has also been reported to increase with extended use [7-9]. Adefovir dipivoxil is a nucleotide analogue of adenosine monophosphate and has been shown to be effective in suppressing not only wildtype HBV but also lamivudine-resistant HBV [10, 11].

Lamivudine has been used in Japan since November 2000 for the treatment of patients with chronic hepatitis B. Since December 2004, adefovir, which decreases the incidence of lamivudine-resistant mutations, has been administered to patients demonstrating a flare-up of hepatitis. The aims of this study were to clarify (1) the long-term efficacy of the lamivudine treatment of Japanese patients with chronic hepatitis B with or without adefovir add-on treatment of breakthrough hepatitis due to lamivudine resistance, (2) the rate of both occurrence of the lamivudine-resistant mutant virus and recurrence of hepatitis related to the lamivudine-resistant virus, and (3) the long-term consequences of the lamivudine and adefovir combination therapy for chronic hepatitis B.

\section{Patients and methods}

Eligible patients were enrolled at Fukuoka University Hospital. The key inclusion criteria were seropositivity for hepatitis B surface antigen and serum HBV DNA. Both HBeAg-positive and HBeAg-negative patients were included. Lamivudine was administered orally at a dose of $100 \mathrm{mg}$ daily for the treatment of the patients who had elevated ALT levels, namely, more than 1.5 times the upper limit of normal. Exclusion criteria included decompensated liver disease, a coexisting serious medical or psychiatric illness, a history of alcohol or drug abuse within 1 year before entry, and coinfection with hepatitis $C$ virus or human immunodeficiency virus, and advanced hepatocellular carcinoma. We examined the effects of the lamivudine treatment on the normalization of the ALT levels, the loss of $\mathrm{HBeAg}, \mathrm{HBeAg}$ seroconversion, and the loss of serum HBV DNA at 1, 2, 3, 4, and 5 years, respectively. To determine the factors that influenced the occurrence of lamivudine-resistant mutation in $\mathrm{HBV}$, we also examined the pre-treatment clinical factors.

Among the patients who developed a lamivudine-resistant virus, the patients who showed an elevated ALT levels of more than two times the upper limit of normal and that continued for longer than 2 months received adefovir at an oral dose of $10 \mathrm{mg}$ daily in addition to lamivudine. In those patients who had adefovir in addition to lamivudine for the treatment of recurrence hepatitis, we examined the effect of the adefovir treatment on the normalization of the ALT levels and the loss of serum HBV DNA since the time the adefovir treatment was started. Furthermore, we studied the efficacy of this combination therapy on the normalization of the ALT levels and the loss of serum HBV DNA at 1, 2, 3,4 , and 5 years, respectively, since the time the lamivudine treatment was started.

The histologic improvement was analyzed in 15 patients who underwent a second liver biopsy. The patients were subjected to a liver biopsy using a Menghini needle guided by ultrasonography. Formalin-fixed liver specimens were stained with hematoxylin and eosin for morphologic evaluations, with Masson's trichrome staining for the assessment of fibrosis. 
$\mathrm{HBeAg}$ and $\mathrm{HBeAb}$ were detected via a chemiluminescent enzyme immunoassay (ARCHITECT HBeAg and ARCHITECT HBeAb, Abbott Japan, Tokyo, Japan). The serum HBV DNA levels in all patients before and during lamivudine treatment were measured via Transcription Mediated Amplification (DNA probe [FR]-HBV; Fujirebio Inc, Tokyo, Japan). The HBV levels were expressed as the log genome equivalent per milliliter (LGE/ml) and the upper and lower detection limits of the assay were 8.7 and $3.7 \log$ copies $/ \mathrm{ml}$, respectively. The incidence of lamivudine mutations in the tyrosine-methionine-aspartateaspartate (YMDD) motif was measured by means of a polymerase chain reaction-enzyme linked mini-sequence assay (PCR-ELMA; SMITEST HBV-YMDD Mutation Detection Kit, Medical and Biological Laboratories, Nagano, Japan).

\section{Statistical analysis}

Fisher's exact test was used for sex and $\mathrm{HBeAg}$ positivity for comparisons between groups. Comparisons of the means \pm standard deviations were performed using Student's $t$-test for age, the ALT level, and the serum HBV DNA level. A $P$-value of less than 0.05 was considered to be statistically significant. For multivariate analyses, the Cox proportional hazards model analysis was used. Ninetyfive CIs were used throughout.

\section{Results}

Patients ( $n=327$ ) who were seropositive for hepatitis B surface antigen were from our hospital and all were Japanese patients. Among these cases, 141 patients received lamivudine as the therapy for chronic hepatitis B and 110 eligible patients have been followed for more than 1 year (67 patients who were $\mathrm{HBeAg}$-positive and 43 patients who were HBeAg-negative) (Table 1). This study reviewed the cumulative outcome of the patients with chronic hepatitis B who were treated with lamivudine, and the patients who had been followed for more than 2, 3, 4, and 5 years numbered 94, 79, 63, and 44, respectively. The median follow-up after the start of lamivudine was 48 (range $=12-86$ ) months. In all patients, including those who were either $\mathrm{HBeAg}$-positive or $\mathrm{HBeAg}$-negative, the normalization of ALT levels decreased with the duration of lamivudine treatment from $70.0 \%$ at 1 year to $56.4 \%$, $48.3 \%, 49.2 \%$, and $36.4 \%$ at 2, 3, 4, and 5 years and the loss of serum HBV DNA decreased from $72.7 \%$ at 1 year to $53.2 \%, 41.8 \%, 39.7 \%$, and $31.8 \%$ at $2,3,4$, and 5 years, respectively (Table 2 ). These results included all the patients with or without lamivudine resistance. In our intention-to-treat analysis, the patients who had an efficacy of adefovir salvage treatment of breakthrough hepatitis were excluded from the efficacy group of lamivudine treatment. In the $\mathrm{HBeAg}$-positive patients, the normalization of the ALT levels decreased during the lamivudine treatment from $71.6 \%$ at 1 year to $55.7 \%$, $42.6 \%, 41.9 \%$, and $22.6 \%$ at 2, 3, 4, and 5 years, respectively (Table 2). Their loss of serum HBV DNA was $22.6 \%$ and $\mathrm{HBeAg}$ seroconversion was $22.6 \%$ during the 5-year period of lamivudine treatment. In the $\mathrm{HBeAg-negative} \mathrm{patients,} \mathrm{the}$ normalization of the ALT levels was $67.4 \%$ at 1 year and $57.6 \%, 60.0 \%, 65.0 \%$, and $69.2 \%$ at $2,3,4$, and 5 years and the loss of serum HBV DNA was $76.7 \%$ at 1 year and $69.7 \%, 66.0 \%, 53.0 \%$, and $53.8 \%$ at $2,3,4$, and 5 years, respectively.

The occurrence of a lamivudine-resistant mutation was seen in 60 patients. The mutation proportion increased from $27.3 \%$ at 1 year to $43.6 \%, 50.1 \%, 53.6 \%$, and $54.6 \%$
Table 1 Patients baseline demographics and disease characteristics $(n=110)$

\begin{tabular}{ll} 
HBeAg: Hepatitis B e antigen & Mean \pm SD \\
$\begin{array}{l}\text { a The upper limit of the normal } \\
\text { range is } 30 \mathrm{IU} \text { per liter }\end{array}$ & Redian \\
\cline { 2 - 2 }
\end{tabular}

\begin{tabular}{llll}
\hline & $\begin{array}{l}\text { HBeAg-positive } \\
n=67\end{array}$ & $\begin{array}{l}\text { HBeAg-negative } \\
n=43\end{array}$ & $\begin{array}{l}\text { All patients } \\
n=110\end{array}$ \\
\hline $\begin{array}{l}\text { Gender, male:female (\%male) } \\
\text { Age (years) }\end{array}$ & $43: 24(64.2 \%)$ & $29: 14(67.4 \%)$ & $72: 38(65.6 \%)$ \\
$\quad$ Mean \pm SD & $41.0 \pm 12.5$ & $47.9 \pm 9.4$ & $43.7 \pm 11.9$ \\
$\quad$ Median & 42 & 47 & 45 \\
$\quad$ Range & $18-68$ & $27-69$ & $18-69$ \\
Alanine aminotransferase (IU/l) & & & $199.3 \pm 244.8$ \\
$\quad$ Mean \pm SD & $208.5 \pm 246.9$ & $185.4 \pm 238$ & 92 \\
$\quad$ Median & 110 & 89 & $45-1148$ \\
Range & $45-1148$ & $45-907$ & \\
HBV DNA (LGE/ml) & & & $6.99 \pm 1.62$ \\
Mean \pm SD & $7.52 \pm 1.06$ & $6.16 \pm 1.95$ & 3.3 \\
Median & 7.6 & 6.9 & $3.7-8.7$ \\
Range & $4.3-8.7$ & $3.7-8.4$ & \\
\hline
\end{tabular}


Table 2 The efficacy of lamivudine treatment in the patients with or without lamivudine-resistance $(n=110)$

\begin{tabular}{|c|c|c|c|c|c|}
\hline & At 1 year $(n=110)$ & At 2 years $(n=94)$ & At 3 years $(n=79)$ & At 4 years $(n=63)$ & At 5 years $(n=44)$ \\
\hline \multicolumn{6}{|l|}{ All patients $(n=110)$} \\
\hline ALT normalization & $77(70.0 \%)$ & $53(56.4 \%)$ & $38(48.3 \%)$ & $31(49.2 \%)$ & $16(36.4 \%)$ \\
\hline \multirow[t]{2}{*}{ Loss of HBV DNA } & $80(72.7 \%)$ & $50(53.2 \%)$ & $33(41.8 \%)$ & $25(39.7 \%)$ & $14(31.8 \%)$ \\
\hline & At 1 year $(n=67)$ & At 2 years $(n=61)$ & At 3 years $(n=54)$ & At 4 years $(n=43)$ & At 5 years $(n=31)$ \\
\hline \multicolumn{6}{|c|}{ HBeAg-positive patients $(n=67)$} \\
\hline ALT normalization & $48(71.6 \%)$ & $34(55.7 \%)$ & $23(42.6 \%)$ & $18(41.9 \%)$ & $7(22.6 \%)$ \\
\hline Loss of HBV DNA & $47(70.1 \%)$ & $27(44.3 \%)$ & $19(35.2 \%)$ & $14(32.6 \%)$ & $7(22.6 \%)$ \\
\hline Loss of $\mathrm{HBeAg}$ & $20(29.9 \%)$ & $20(32.8 \%)$ & $19(35.2 \%)$ & $13(30.2 \%)$ & $7(22.6 \%)$ \\
\hline \multirow[t]{2}{*}{$\mathrm{HBe} A g$ seroconversion } & $16(23.9 \%)$ & $9(31.1 \%)$ & $18(33.3 \%)$ & $13(30.2 \%)$ & $7(22.6 \%)$ \\
\hline & At 1 year $(n=43)$ & At 2 years $(n=33)$ & At 3 years $(n=25)$ & At 4 years $(n=20)$ & At 5 years $(n=13)$ \\
\hline \multicolumn{6}{|c|}{ HBeAg-negative patients $(n=43)$} \\
\hline ALT normalization & $29(67.4 \%)$ & $19(57.6 \%)$ & $15(60.0 \%)$ & $13(65.0 \%)$ & $9(69.2 \%)$ \\
\hline Loss of HBV DNA & $33(76.7 \%)$ & $23(69.7 \%)$ & $14(66.0 \%)$ & $11(53.0 \%)$ & $7(53.8 \%)$ \\
\hline
\end{tabular}

ALT: Alanine aminotransferase

HBeAg: Hepatitis B e antigen

at 2, 3, 4, and 5 years of treatment, respectively. Table 3 shows the number of patients who developed virus recrudescence at each year. This occurrence was more frequent in those who were HBeAg-positive $(P<0.01)$, those with a low ALT level $(P<0.05)$, and those with a high level of serum HBV DNA $(P<0.01)$ at the time the lamivudine treatment was started (Table 4$)$. Thirty-six $(60.0 \%)$ of the

Table 3 The occurrence of lamivudine-resistant mutation during 5 years

\begin{tabular}{lcl}
\hline & $\begin{array}{l}\text { Number of } \\
\text { patients }\end{array}$ & $\begin{array}{l}\text { Baseline HBV DNA levels } \\
\text { Mean } \pm \text { SD (LGE/ml) }\end{array}$ \\
\hline At 1 year & 30 & $7.46 \pm 1.15$ \\
At 2 years & 18 & $7.56 \pm 1.07$ \\
At 3 years & 8 & $6.98 \pm 2.35$ \\
At 4 years & 3 & $7.46 \pm 0.70$ \\
At 5 years & 1 & 6.3 \\
\hline
\end{tabular}

60 patients received adefovir for the treatment of breakthrough hepatitis due to a lamivudine-resistant mutation, whereas the other 24 patients with a slight elevation in the ALT level did not receive adefovir. The patients who received adefovir had significantly higher levels of serum HBV DNA at the time the lamivudine treatment was started than those who did not receive adefovir (Table 5). Cox proportional hazards model analysis was used to determine the factors predicting viral recrudescence and breakthrough hepatitis. The patients who had more than 7.0 LGE/ml of serum HBV DNA level at the time the lamivudine treatment was started showed a significantly frequent occurrence of a lamivudine-resistant mutation (risk ratio $=0.466,95 \%$ CI: $0.246-0.842, P=0.011$; Table 6). The patients who had more than $7.7 \mathrm{LGE} / \mathrm{ml}$ of serum HBV DNA at the time the lamivudine treatment was started more frequently received adefovir add-on therapy for breakthrough hepatitis (risk ratio $=0.444,95 \% \mathrm{CI}$ : 0.218-0.879, $P=0.019$; Table 6).
Table 4 Comparison between those patients who had virus recrudescence and those who did not

HBeAg: Hepatitis B e antigen NS: Not significant

\begin{tabular}{llll}
\hline & $\begin{array}{l}\text { Virus recrudescence } \\
(n=60)\end{array}$ & $\begin{array}{l}\text { Non-virus recrudescence } \\
(n=50)\end{array}$ & $P$ \\
\hline Age (years) mean \pm SD & $43.5 \pm 11.4$ & $44.4 \pm 12.3$ & NS \\
Gender: male:female (\%male) & $44: 16(73.3 \%)$ & $28: 22(56.0 \%)$ & NS \\
HBeAg-positive patients & $44(73.3 \%)$ & $23(46.0 \%)$ & $<0.01$ \\
$\begin{array}{l}\text { Alanine aminotransferase (IU/l) } \\
\quad \text { Mean } \pm \text { SD }\end{array}$ & $157.9 \pm 218.5$ & $246.6 \pm 261.6$ & $<0.05$ \\
$\quad \begin{array}{l}\text { Serum HBV DNA (LGE/ml) } \\
\quad \text { Mean } \pm \text { SD }\end{array}$ & $7.40 \pm 1.36$ & $6.49 \pm 1.75$ & $<0.01$ \\
\hline
\end{tabular}


Table 5 Comparison between those patients who received adefovir and those who did not

HBeAg: Hepatitis B e antigen NS: Not significant

YMDD mutation: YMDD motif of the HBV DNA polymerase YIDD: Methionine to isoleucine YVDD: Methioneine to valine

\begin{tabular}{|c|c|c|c|c|c|}
\hline & $\begin{array}{l}\text { Administration of } \\
\text { adefovir }(n=36)\end{array}$ & & $\begin{array}{l}\text { No administration of } \\
\text { adefovir }(n=24)\end{array}$ & & $P$ \\
\hline Age (years) mean $\pm S D$ & $45.0 \pm 10.5$ & & $41.3 \pm 12.3$ & & NS \\
\hline Gender: male:female (\%male) & $29: 7(80.1 \%)$ & & $15: 9(62.5 \%)$ & & NS \\
\hline $\mathrm{HBeAg}$-positive patients & $25(69.4 \%)$ & & $19(79.2 \%)$ & & NS \\
\hline \multicolumn{6}{|l|}{ Alanine aminotransferase (IU/l) } \\
\hline Mean \pm SD & $148.7 \pm 202.5$ & & $170.0 \pm 239.6$ & & NS \\
\hline \multicolumn{6}{|l|}{ Serum HBV DNA (LGE/ml) } \\
\hline Mean $\pm \mathrm{SD}$ & $7.64 \pm 1.03$ & & $6.91 \pm 1.30$ & & $<0.05$ \\
\hline \multirow[t]{3}{*}{ YMDD mutation } & YIDD & 20 & YIDD & 13 & \\
\hline & YVDD & 8 & YVDD & 4 & \\
\hline & YIDD + YVDD & 3 & YIDD + YVDD & 0 & \\
\hline
\end{tabular}

Table 6 Multivariate analysis with Cox proportional hazards model

\begin{tabular}{llllr}
\hline & Variable & $P$-value & Risk ratio & $95 \%$ CI \\
\hline Virus recrudescence & HBV DNA $\geqq 7.0 \mathrm{LGE} / \mathrm{ml}$ & 0.011 & 0.466 & $0.246-0.842$ \\
Breakthrough & HBV DNA $\geqq 7.7 \mathrm{LGE} / \mathrm{ml}$ & 0.019 & 0.444 & $0.218-0.879$ \\
\hline
\end{tabular}

Only variables that achieved statistical significance $(P<0.05)$ are shown

CI: Confidence interval

Breakthrough; administration of adefovir for breakthrough hepatitis due to lamivudine resistance

Table 7 The efficacy of the adefovir add-on treatment

\begin{tabular}{|c|c|c|c|}
\hline & At 1 year $(n=36)$ & At 2 years $(n=19)$ & At 3 years $(n=11)$ \\
\hline \multicolumn{4}{|l|}{ All patients $(n=36)$} \\
\hline ALT Normalization & $17(47.2 \%)$ & $11(57.9 \%)$ & $9(81.8 \%)$ \\
\hline \multirow[t]{2}{*}{ Loss of HBV DNA } & $17(47.2 \%)$ & $13(68.4 \%)$ & $10(90.9 \%)$ \\
\hline & At 1 year $(n=25)$ & At 2 year $(n=13)$ & At 3 years $(n=8)$ \\
\hline \multicolumn{4}{|c|}{ HBeAg-positive patients $(n=25)$} \\
\hline ALT Normalization & $12(48.0 \%)$ & $7(53.8 \%)$ & $7(87.5 \%)$ \\
\hline Loss of HBV DNA & $9(36.0 \%)$ & $8(61.5 \%)$ & $7(87.5 \%)$ \\
\hline Loss of $\mathrm{HBeAg}$ & $3(12.0 \%)$ & $5(38.5 \%)$ & $6(75.0 \%)$ \\
\hline \multirow[t]{2}{*}{$\mathrm{HBeAg}$ seroconversion } & $3(12.0 \%)$ & $5(38.5 \%)$ & $6(75.0 \%)$ \\
\hline & At 1 year $(n=11)$ & At 2 year $(n=6)$ & At 3 years $(n=3)$ \\
\hline \multicolumn{4}{|c|}{ HBeAg-negative patients $(n=11)$} \\
\hline ALT Normalization & $5(45.5 \%)$ & $4(66.7 \%)$ & $2(66.7 \%)$ \\
\hline Loss of HBV DNA & $8(72.7 \%)$ & $5(83.3 \%)$ & $3(100 \%)$ \\
\hline
\end{tabular}

ALT: Alanine aminotransferase

HBeAg: Hepatitis B e antigen

Of these 36 patients who received adefovir, the normalization of ALT levels was $47.2 \%, 57.9 \%$, and $81.8 \%$ at 1,2 , and at 3 years and their loss of serum HBV DNA was $47.2 \%, 68.4 \%$, and $90.9 \%$ at 1,2 , and at 3 years, respectively (Table 7). At the time of this analysis, the median total duration of adefovir treatment was 24 (range $=12-$
56) months and no adefovir-resistant mutation has been detected in any of these patients.

Fifty patients who did not develop lamivudine resistance showed the normalization of their ALT levels to be $84.0 \%$ at 1 year and $86.1 \%, 92.0 \%, 90.9 \%$, and $91.9 \%$ at $2,3,4$, and 5 years and the loss of serum HBV DNA was 

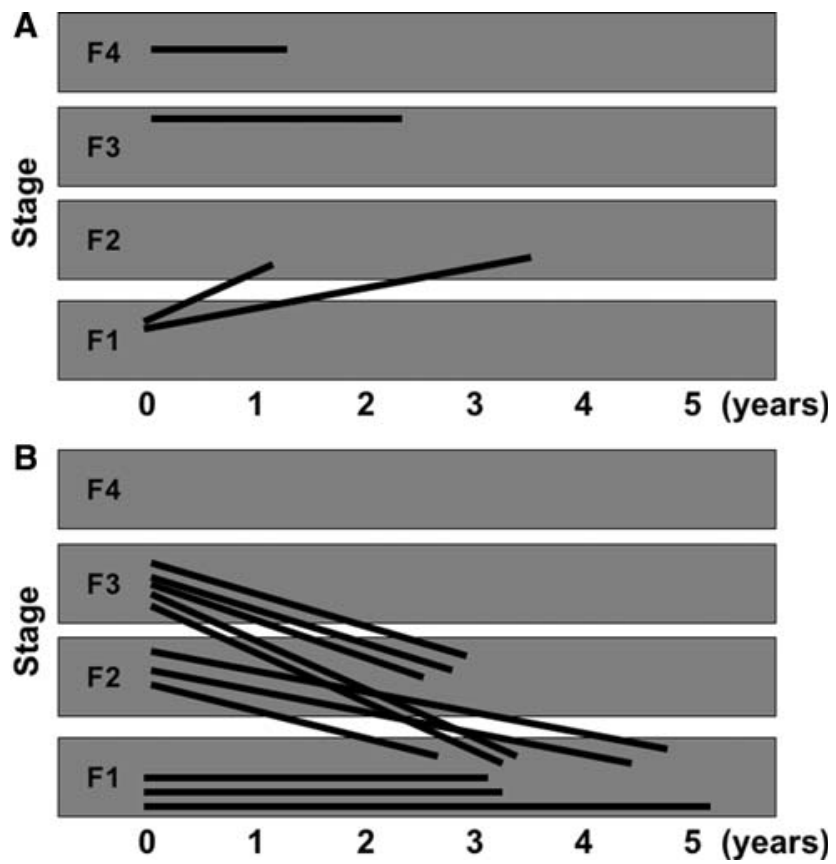

Fig. 1 A follow-up study of liver histology on the patients with chronic hepatitis B treated with lamivudine. (a) Four patients whose alanine aminotransferase levels were more than 2 times the upper limit of normal showed no improvement in liver fibrosis at the second liver biopsy. (b) Nine patients whose alanine aminotransferase levels were less than 2 times the upper limit of normal demonstrated an improvement in liver fibrosis at the second liver biopsy even if the serum HBV DNA was positive. Another 3 patients whose degree of fibrosis was diagnosed to be F1 at the first liver biopsy showed no change in liver fibrosis
$92.0 \%$ at 1 year and $94.4 \%, 96.0 \%, 95.5 \%$, and $100 \%$ at 2, 3, 4, and 5 years, respectively. The results were good for the patients who did not develop lamivudine resistance.

Fifteen patients who were treated with lamivudine underwent a repeat liver biopsy. The changes in stages of liver fibrosis are shown in Fig. 1. Figure 1a shows the group of the patients whose ALT levels were more than two times the upper limit of normal. Figure $1 \mathrm{~b}$ shows the group of the patients whose ALT levels were less than two times the upper limit of normal. A progression in the fibrosis stage was observed in two patients and an improvement in the fibrosis stage was observed in 8 patients. Even if the serum HBV DNA level showed positive values, the degree of liver fibrosis improved on the basis of the findings of a second liver biopsy in the patients who were treated with lamivudine if the ALT level was less than two times the upper limit of normal.

To clarify the long-term efficacy of the lamivudine treatment of Japanese patients with chronic hepatitis B with or without adefovir add-on treatment of breakthrough hepatitis due to lamivudine-resistance, we investigated the efficacy of the lamivudine treatment by our new approach. Table 2 shows those patients who had an efficacy of adefovir salvage treatment of breakthrough hepatitis and were excluded from the efficacy group of the patients with lamivudine treatment. In addition, in Table 8, the patients who had the efficacy of adefovir add-on treatment were included in the efficacy group for 5-year period since lamivudine treatment was started. These results included all the patients

Table 8 The efficacy of lamivudine treatment with or without adefovir add-on $(n=110)$

\begin{tabular}{|c|c|c|c|c|c|}
\hline & At 1 year $(n=110)$ & At 2 years $(n=94)$ & At 3 years $(n=79)$ & At 4 years $(n=63)$ & At 5 years $(n=44)$ \\
\hline \multicolumn{6}{|l|}{ All patients $(n=110)$} \\
\hline ALT normalization & $77(70.0 \%)$ & $55(58.5 \%)$ & $48(60.8 \%)$ & $42(66.7 \%)$ & $27(61.4 \%)$ \\
\hline \multirow[t]{2}{*}{ Loss of HBV DNA } & $80(72.7 \%)$ & $55(58.5 \%)$ & $43(54.4 \%)$ & $36(57.1 \%)$ & $27(61.4 \%)$ \\
\hline & At 1 year $(n=67)$ & At 2 years $(n=61)$ & At 3 years $(n=54)$ & At 4 years $(n=43)$ & At 5 years $(n=31)$ \\
\hline \multicolumn{6}{|c|}{ HBeAg-positive patients $(n=67)$} \\
\hline ALT normalization & $48(71.6 \%)$ & $34(55.7 \%)$ & $29(53.7 \%)$ & $26(60.5 \%)$ & $17(54.8 \%)$ \\
\hline Loss of HBV DNA & $47(70.1 \%)$ & $27(44.3 \%)$ & $24(44.4 \%)$ & $21(48.8 \%)$ & $16(51.6 \%)$ \\
\hline Loss of $\mathrm{HBeAg}$ & $20(29.9 \%)$ & $20(32.8 \%)$ & $20(37.0 \%)$ & $18(41.9 \%)$ & $14(45.2 \%)$ \\
\hline \multirow[t]{2}{*}{$\mathrm{HBeAg}$ seroconversion } & $16(23.9 \%)$ & $19(31.1 \%)$ & $19(35.2 \%)$ & $18(41.9 \%)$ & $14(45.2 \%)$ \\
\hline & At 1 year $(n=43)$ & At 2 years $(n=33)$ & At 3 years $(n=25)$ & At 4 years $(n=20)$ & At 5 years $(n=13)$ \\
\hline \multicolumn{6}{|c|}{ HBeAg-negative patients $(n=43)$} \\
\hline ALT Normalization & $29(67.4 \%)$ & $21(63.6 \%)$ & $19(76.0 \%)$ & $16(80.0 \%)$ & $10(76.9 \%)$ \\
\hline Loss of HBV DNA & $33(76.7 \%)$ & $28(84.8 \%)$ & $19(76.0 \%)$ & $15(75.0 \%)$ & $11(84.6 \%)$ \\
\hline
\end{tabular}

ALT: Alanine aminotransferase

HBeAg: Hepatitis B e antigen 
with or without lamivudine-resistance and all the patients with or without adefovir add-on therapy. In all these patients, including those who were $\mathrm{HBeAg}$-positive and those who were HBeAg-negative, the normalization of the ALT levels was $61.4 \%$ at 5 years since lamivudine treatment was started (Table 8 ). The loss of serum HBV DNA was $61.4 \%$ at 5 years since the lamivudine treatment was started. In the $\mathrm{HBeAg}$-positive patients, the normalization of the ALT levels, the loss of serum HBV DNA, and HBeAg seroconversion was $54.8 \%, 51.6 \%$, and $45.2 \%$ at 5 years, respectively, since the lamivudine treatment was started. In the HBeAg-negative patients, the normalization of the ALT levels and the loss of serum HBV DNA was $76.9 \%$ and $84.6 \%$ at 5 years, respectively, since the lamivudine treatment had been started.

\section{Discussion}

We herein describe the long-term efficacy of lamivudine treatment over a 5-year period. In all patients, including those who were $\mathrm{HBeAg}$-positive and those who were HBeAg-negative, the normalization of ALT levels and the loss of serum HBV DNA gradually decreased to $36.4 \%$ and $31.8 \%$ at 5 years, respectively. The efficacy of lamivudine treatment was only about $30 \%$. This result showed that lamivudine monotherapy could not improve the long-term outcomes in the patients with chronic hepatitis B. However, in the HBeAg-negative patients, the effects of lamivudine treatment were maintained for long-term. Although we assessed only a small number of patients in this study, we consider lamivudine monotherapy to be an effective treatment modality for patients with $\mathrm{HBeAg-}$ negative chronic hepatitis $\mathrm{B}$ to improve the long-term outcomes. On the other hand, because in the $\mathrm{HBeAg-}$ positive patients, virus recrudescence was more frequently observed than in the HBeAg-negative patients, the efficacy of the lamivudine treatment for 5 years was only about $20 \%$. HBeAg-positive patients who demonstrated a high value of serum HBV DNA level and a low ALT level at the start of the lamivudine therapy showed a significant correlation with an increase in the occurrence of lamivudineresistant mutations. Our Cox proportional hazards model analysis shows that to obtain serum HBV DNA levels of less than $7.7 \mathrm{LGE} / \mathrm{ml}$ before lamivudine treatment might associate with good outcomes in those patients. These patients are therefore recommended to reduce their serum HBV DNA levels before commencing lamivudine treatment and using interferon $\alpha$ or other therapeutic options [5, $6,12]$. Further large-scale and long-term studies are needed to confirm these observations.

In our study, although most virus recrudescence was observed within 1 year after the lamivudine treatment, 1 patient demonstrated virus recrudescence at 5 years after the lamivudine treatment was started. This is a very important finding and we must therefore carefully monitor the serum HBV DNA levels of the patients even if they show a good long-term response to the lamivudine treatment. Thirty-six of the patients with virus-recrudescence had adefovir added to the lamivudine regimen for the treatment of breakthrough hepatitis. However, the other 24 patients $(40 \%)$ did not need adefovir to be added to the treatment regimen because they did not demonstrate hepatitis. In our study, even if the serum HBV DNA level was found to be positive, a histologic improvement was obtained in patients with ALT levels that were under 2 times the upper limit of normal at the time of a second liver biopsy. We thus consider that the normalization of ALT levels might therefore be more important than achieving a negative serum HBV DNA state to achieve a remission of liver disease. However, the risks of hepatocellular carcinoma and cirrhosis in the patients with chronic hepatitis B have recently been reported to be related to the serum HBV DNA levels [13, 14]. Our 24 patients who did not have adefovir added to the treatment regimen, even if they had virus recrudescence, all required a long-term follow-up to monitor whether or not they might progress to either cirrhosis or hepatocellular carcinoma.

Some reports have shown that among patients who experienced $\mathrm{HBeAg}$ seroconversion during the lamivudine treatment, the durability of the response after the cessation of therapy ranged from $38 \%$ to $77 \%$ [15-17]. Because lamivudine therapy still continues to be administered in Japan to avoid any posttreatment flare-ups of hepatitis [18-20], our patients continue to receive lamivudine treatment; therefore, our data are not comparable with other studies involving a cessation of treatment.

Previous studies reported that in patients receiving adefovir, the HBV DNA level decreased by 3.5 to $3.9 \log _{10}$ from the baseline level [21, 22]. In addition, studies from Asia reported that patients with lamivudine resistance have been treated with adefovir either in monotherapy or in combination with lamivudine without any significant differences between the 2 regimens [23, 24]. On the other hand, studies from Europe reported that adding adefovir to lamivudine for the treatment of patients with lamivudineresistant $\mathrm{HBeAg}$-negative chronic hepatitis $\mathrm{B}$ maximizes the anti-viral efficacy because of the absence of viral resistance [25, 26]. In Japan, adefovir has been used as an additional therapy to suppress viral replication with lamivudine-resistant mutations. In all the patients investigated in our study, adefovir was added to the lamivudine regimen. However, no virologic or biochemical breakthrough was reported because no adefovir-resistance occurred in any of our patients. We thus considered that the condition of no adefovir-resistance might have occurred as all 
our patients received adefovir in combination with lamivudine.

To clarify the long-term efficacy of the lamivudine treatment of Japanese patients with chronic hepatitis B, we investigated the efficacy of lamivudine treatment on the basis of our new approach. In all the patients with or without lamivudine resistance and with or without adefovir add-on treatment, the normalization of the ALT levels was $61.4 \%$ and the loss of serum HBV DNA was $61.4 \%$ after the 5-year period of treatment from the time of lamivudinetreatment. This study is the first report to clarify the longterm efficacy of lamivudine treatment either with or without adefovir from the time the lamivudine treatment was started. Our study suggests that even in patients with chronic hepatitis B who have a high HBV DNA level and/ or who are $\mathrm{HBeAg}$-positive, the combination therapy of lamivudine and adefovir appears to be an effective treatment modality. This is a retrospective observational study with a relatively heterogeneous patient population. Although this study has its limitation, it represents the real situation for the treatment of chronic hepatitis B in Japan. The advantages of this study, such as being a single-center study, where all tests were performed in the same laboratory using the same methods, are thus considered to outweigh these limitations. These preliminary observations need to be validated in future studies with a larger number of patients.

In conclusion, although the efficacy of lamivudine is limited because of breakthrough hepatitis, adefovir was used as a salvage treatment of lamivudine resistance in patients with chronic hepatitis B. Therefore, the use of lamivudine for the treatment of Japanese patients with chronic hepatitis B with or without lamivudine-resistance is thus considered to be a useful treatment modality for obtaining long-term virologic and biochemical responses.

Open Access This article is distributed under the terms of the Creative Commons Attribution Noncommercial License which permits any noncommercial use, distribution, and reproduction in any medium, provided the original author(s) and source are credited.

\section{References}

1. Lee WM. Hepatitis B virus infection. N Engl J Med 1997; 337:1733-45.

2. World Health Organization. Fact sheet WHO/204. Hepatitis B. Geneva, Switzerland: World Health Organization; 2003.

3. Beasley RP. Hepatitis B virus: the major etiology of hepatocellular carcinoma. Cancer 1988;61:1942-56.

4. Hepatitis B fact sheet. Atlanta, GA: National Center for Infectious Disease, Centers for Disease Control and Prevention; 2004.

5. Wong DK, Cheung AM, O'Rourke K, Naylor CD, Detsky AS, Heathcote J. Effect of alpha-interferon treatment with hepatitis $\mathrm{B}$ e antigen-positive chronic hepatitis B. A meta-analysis. Ann Intern Med 1993;119:312-23.
6. Manesis EK, Hadziyannis SJ. Interferon $\alpha$ treatment and retreatment of hepatitis B e antigen-negative chronic hepatitis B. Gastroenterology 2001;121:101-9.

7. Liaw YF, Chien RN, Yeh CT, Tsai SL, Chu CM. Acute exacerbation and hepatitis $\mathrm{B}$ virus clearance after emergence of YMDD motif mutation during lamivudine therapy. Hepatology 1999;30:567-72.

8. Hadziyannis SJ, Papatheodoridis GV, Dimou E, Laras A, Papaioannou C. Efficacy of long-term lamivudine monotherapy in patients with hepatitis B e antigen-negative chronic hepatitis B. Hepatology 2000;32:847-51.

9. Liaw YF. Impact of YMDD mutations during lamivudine therapy in patients with chronic hepatitis B. Antivir Chem Chemother 2001;12:67-71.

10. Peters M, Hann HWH, Martin P, Heathcote EJ, Buggisch P, Rubin R, et al. Adefovir dipivoxil alone or in combination with lamivudine in patients with lamivudine-resistant chronic hepatitis B. Gastroenterology 2004;126:91-101.

11. Hadziyannis SJ, Tassopoulos NC, Heathcote EJ, Chang TT, Kitis G, Rizzetto M, et al. Long-term therapy with adefovir dipivoxil for HBeAg-negative chronic hepatitis B. N Engl J Med 2005;352:2673-81.

12. Schalm SW, Heathcote J, Cianciara J, Farrell G, Sherman M, Willems B, et al. Lamivudine and alpha interferon combination treatment of patients with chronic hepatitis B infection: a randomised trial. Gut 2000;46:562-8.

13. Iloeje UH, Yang HI, Su J, Jen CL, You SL, Chen CJ. Predicting cirrhosis risk based on the level of circulating hepatitis B viral load. Gastroenterology 2006;130:678-86.

14. Chen CJ, Yang HI, Su J, Jen CL, You SL, Lu SN, et al. Risk of hepatocellular carcinoma across a biological gradient of serum hepatitis B virus DNA level. JAMA 2006;295:65-73.

15. Lee KM, Cho SW, Kim SW, Kim HJ, Hahm KB, Kim JH. Effect of virological response on post-treatment durability of lamivudine-induced HBeAg seroconversion. J Viral Hepat 2002;9:20812.

16. Dienstag JL, Cianciara J, Karayalcin S, Kowdley KV, Willems B, Plisek S, et al. Durability of serologic response after lamivudine treatment of chronic hepatitis B. Hepatology 2003;37:748-55.

17. van Nunen AB, Hansen BE, Suh DJ, Lohr HF, Chemello L, Fontaine H, et al. Durability of $\mathrm{HBeAg}$ seroconversion following antiviral therapy for chronic hepatitis B: relation to type of therapy and pretreatment serum hepatitis B virus DNA and alanine aminotransferase. Gut 2003;52:420-4.

18. Ide T, Kumashiro R, Suzuki H, Tanikawa K, Sata M. Two-year follow-up study after treatment with lamivudine for chronic hepatitis B: seven cases reported. Hepatol Res 2000;17:197-204.

19. Honkoop P, de Man RA, Niesters HG, Zondervan PE, Schalm SW. Acute exacerbation of chronic hepatitis B virus infection after withdrawal of lamivudine therapy. Hepatology 2000; 32:635-9.

20. Bonacini M, Kurz A, Locarnini S, Ayres A, Gibbs C. Fulminant hepatitis $\mathrm{B}$ due to a lamivudine-resistance mutant of $\mathrm{HBV}$ in a patient coinfected with HIV. Gastroenterology 2002;124:244-5.

21. Hadziyannis SJ, Tassopoulos NC, Heathcote EJ, Chang TT, Kitis G, Rizzetto M, et al. Adefovir dipivoxil for the treatment of hepatitis B e antigen-negative chronic hepatitis B. N Engl J Med 2003;348:800-7.

22. Marcellin P, Chang TT, Lim SG, Tong MJ, Sievert W, Shiffman ML, et al. Adefovir dipivoxil for the treatment of hepatitis B e antigen-positive chronic hepatitis B. N Engl J Med 2003;348: 808-16.

23. Dai CY, Chuang WL, Hsieh MY, Lee LP, Huang JF, Hou NJ, et al. Adefovir dipivoxil treatment of lamivudine-resistant chronic hepatitis B. Antivir Res 2007;75:146-51. 
24. Fung J, Lai CL, Yuen JC, Wong DK, Tanaka Y, Mizokami M, et al. Adefovir dipivoxil monotherapy and combination therapy with lamivudine for the treatment of chronic hepatitis B in an Asian population. Antivir Ther 2007;12:41-6.

25. Rapti I, Dimou E, Mitsoula P, Hadziyannis SJ. Adding-on versus switching-to adefovir therapy in lamivudine-resistant $\mathrm{HBeAg}$ negative chronic hepatitis B. Hepatology 2007;45:307-13.
26. Manolakopoulos S, Bethanis S, Koutsounas S, Goulis J, Vlachogiannakos J, Christias E, et al. Long-term therapy with adefovir dipivoxil in hepatitis $\mathrm{B}$ e antigen-negative patients developing resistance to lamivudine. Aliment Pharmacol Ther 2008;27: 266-73. 